\title{
Effect of Cold Storage on Weight Loss and Storage Life of Pomegranate Cv. "Bhagwa"
}

\author{
Dr. Parag Babaji Jadhav*, Mansute Ajinkya, Nikhil Pradip Gurav, Kiran Pokharkar, and \\ Dattatraya B. More
}

Ecofrost Technologies Pvt. Ltd., Survey No 134/1, 134/2, 130/3, Jeevan Nagar, Tathawade, Pune, Maharashtra411033.

*Corresponding Authors: Dr. Parag Babaji Jadhav, Ecofrost Technologies Pvt. Ltd., Survey No 134/1, 134/2, 130/3, Jeevan Nagar, Tathawade, Pune, Maharashtra- 411 033, India.

\begin{abstract}
A tests was conducted to examine the weight loss and storage life of pomegranate fruit $c v$. "Bhagwa” at 'Agricultural Research Laboratory', Ecofrost Technologies Pvt. Ltd., Pune, Maharashtra inside cold room. Weight loss was recorded inside cold room $\left(7^{\circ} \mathrm{C}\right.$ and $\left.95 \% \mathrm{RH}\right)$ as $2.63 \%$ and $7.59 \%$ after days 22 and 30 respectively used CFB box packaging with cushioning material as paper shreds. Post-storage life was recorded 3 days and 2 days after 22 and 30 days respectively at room temperature after taken out from cold room. Shelf life was recorded to be 6 days.
\end{abstract}

Keywords: Pomegranate, Bhagwa, Shendria, Cold room, Ecofrost, etc.

\section{INTRODUCTION}

Pomegranate (Punica granatum) is a wonderful fruit. It is grown in tropical and subtropical regions of the world. It is known for its tiny red seeds that are eaten, which are also called arils. The 'Bhagwa' or 'Shendria' is our next variety, which is originated from crossing the F2 population of Ganesh with the Gulesha Red pomegranate. The crossing makes it attractive on the outside, being a glossy red color.

India tops the list of the world's area and production of pomegranate, and exports much of its supply to the United Arab Emirates, Oman, and the UK. India even ships pomegranates to the countries like US and Canada. The country's main export competitors are Spain and Iran.

Maharashtra is the leading producer of pomegranate followed by Karnataka, Andhra Pradesh, Gujarat and Tamil Nadu. Ganesh, Bhagwa, Ruby, Arakta and Mridula are some of the other varieties of pomegranates produced in Maharashtra. In India, pomegranate is commercially cultivated in Solapur (60 to 70 percent), Sangli, Nashik, Ahmednagar, Pune, Dhule, Aurangabad, Satara, Osmanabad and Latur districts of Maharashtra; Bijapur, Belgaum and Bagalkot districts of Karnataka and to a smaller extent in Gujarat, Andhra Pradesh and Tamilnadu. Fruiting season in various regions is observed as Maharashtra and Gujrat, year-round; Karnataka- January to April; and Andhra Pradesh- March to June.

Pomegranate is one of the healthiest fruit on earth. It is called as a divine fruit. Pomegranate has antioxidant, anti-viral and anti-tumor properties and is said to be a good source of vitamins, especially vitamin $\mathrm{A}$, vitamin $\mathrm{C}$, and vitamin $\mathrm{E}$, as well as folic acid. This amazing fruit consists three times as many antioxidants as both wine or green tea. Consuming pomegranate also lowers the risk of all sorts of diseases.

Pomegranates should harvest when they are fully ripe, have the right size and the right color. The incidence and severity of chilling injury depends upon storage temperature, duration and cultivar. The minimum safe storage temperature is $5^{\circ} \mathrm{C}$ for up to 8 weeks, if decay is not a problem. For longer storage, the temperature should be at $7 \mathrm{oC}$ to avoid chilling injury, but decay (Botrytis cinerea) and weight loss may become a limiting factor. However, pomegranates must be dipped in the fungicide solution because the botrytis spores are usually in the calyx area of the fruit, which is not adequately 
covered by post-harvest spraying during packaging. After dipping, surface moisture must be removed with a fan to eliminate free moisture on the fruit, when stored in a box or bin. Under these storage conditions, pomegranates should be cooled to $7^{\circ} \mathrm{C}$ as soon as possible after harvest. Fruit should be kept at $7^{\circ} \mathrm{C}$ during storage and transportation to attain a post-harvest life longer than 8 weeks, depending on the cultivar and storage relative humidity.

\section{MATERIALS AND MethodS}

The study was carried out at "Agri Research Laboratory" of Ecofrost Technologies Pvt. Ltd., Pune, Maharashtra, India. The Bhagwa fruits were harvested at proper fully matured stage, have well shape and size; and packaged in CFB (Corrugated Fiberboard Box- $(30 \mathrm{~cm}(\mathrm{~W}) * 37 \mathrm{~cm}(\mathrm{~L}) * 10 \mathrm{~cm}(\mathrm{H})$ ). Fruits were handled properly to avoid bruising and mechanical injuries. The fruits were kept inside cold storage at $7{ }^{\circ} \mathrm{C}$, with $95 \%$ relative humidity $(\mathrm{RH})$. Weight loss was recorded with box inside cold room after 22 days and 30 days.

Table1. Weight loss of pomegranate fruits $\mathrm{cv}$. "Bhagwa" inside cold room with Corrugated Fiber Board box packaging

\begin{tabular}{|c|c|c|c|c|}
\hline Sr. No. & $\begin{array}{c}\text { Fruits weight measured } \\
\text { on days }\end{array}$ & $\begin{array}{c}\text { Fruits Weight } \\
(\mathbf{k g})\end{array}$ & $\begin{array}{c}\text { Balanced weight inside } \\
\text { cold room (\%) }\end{array}$ & Weight loss (\%) \\
\hline 1 & Day-0 & 3.8 & 100 & 0.00 \\
\hline 2 & Day-22 & 3.7 & 97.37 & 2.63 \\
\hline
\end{tabular}

Table2. Weight loss of pomegranate fruits $\mathrm{cv}$. "Bhagwa" inside cold room with Corrugated Fiber Board box packaging

\begin{tabular}{|c|c|c|c|c|}
\hline Sr. No. & $\begin{array}{c}\text { Fruits weight measured } \\
\text { on days }\end{array}$ & $\begin{array}{c}\text { Fruits Weight } \\
(\mathbf{k g})\end{array}$ & $\begin{array}{c}\text { Balanced weight inside } \\
\text { cold room (\%) }\end{array}$ & Weight loss (\%) \\
\hline 1 & Day-0 & 3.95 & 100 & 0.00 \\
\hline 2 & Day-30 & 3.65 & 92.41 & 7.59 \\
\hline
\end{tabular}

\section{RESULTS AND DISCUSSION}

Weight loss was recorded $2.63 \%$ after 22 days and $7.59 \%$ after 30 days inside cold room (Table 1 \& 2). Above studies shows that after 22 days, weight loss was drastically increased inside cold room specially reported for the same cultivar as per the experiment.

Shelf life was recorded to be 6 days. Shelf life was decided based on aril colour, shape and fruit rind shriveling [1]. Post-storage life after 22 and 30 days was recorded three days and two days; respectively. Storage of pomegranates inside cold room at temperature $7{ }^{\circ} \mathrm{C}$, with $95 \%$ relative humidity along with CFB box with shredded paper maintain better performance (Plate No 1).

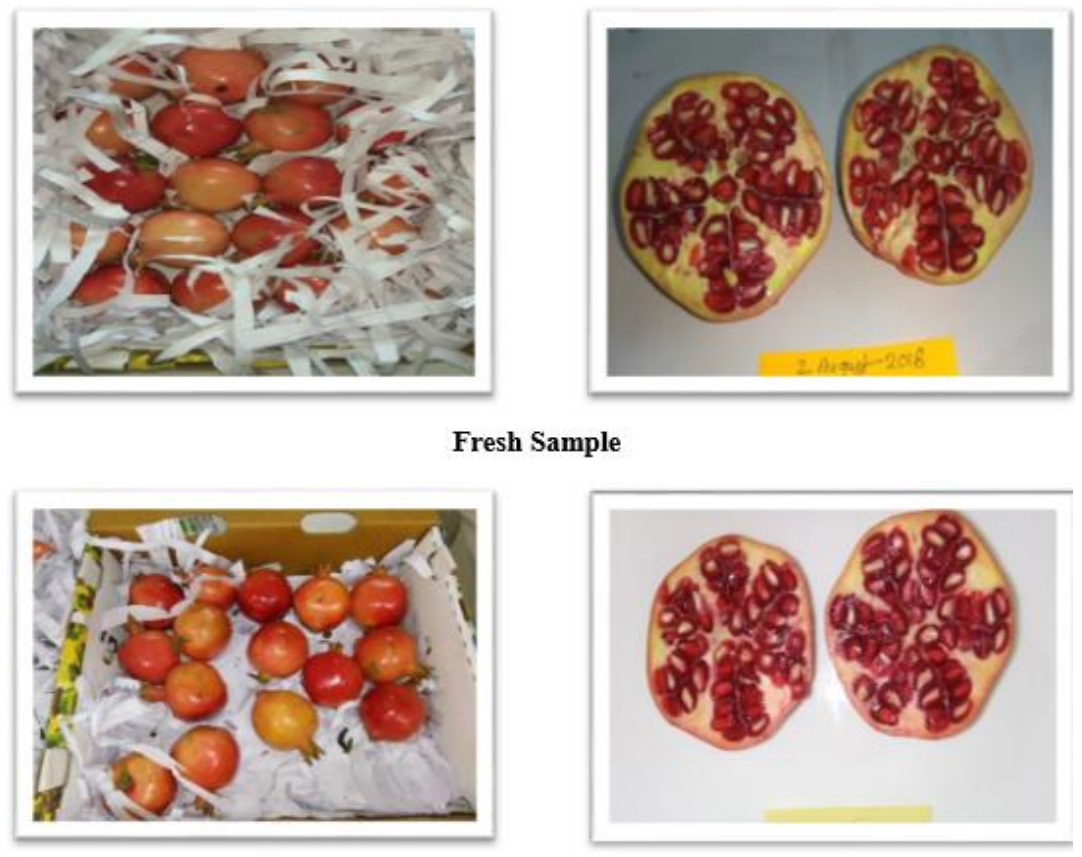

After 22 days 

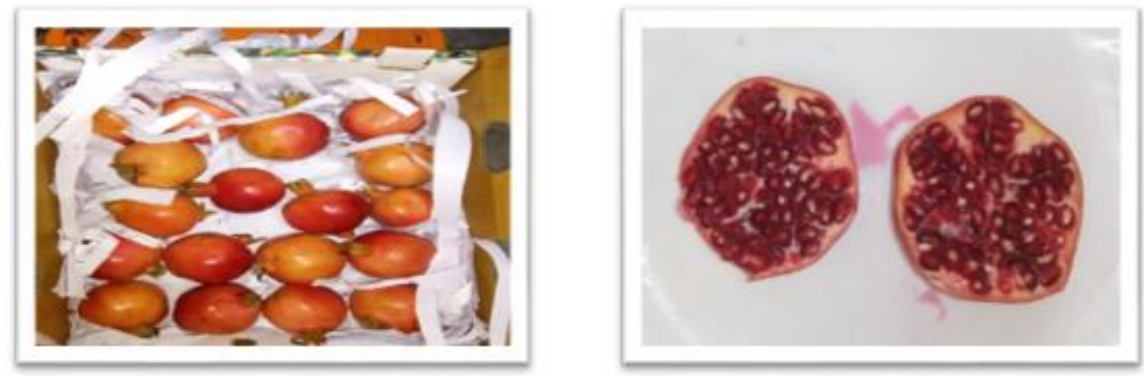

After 30 days
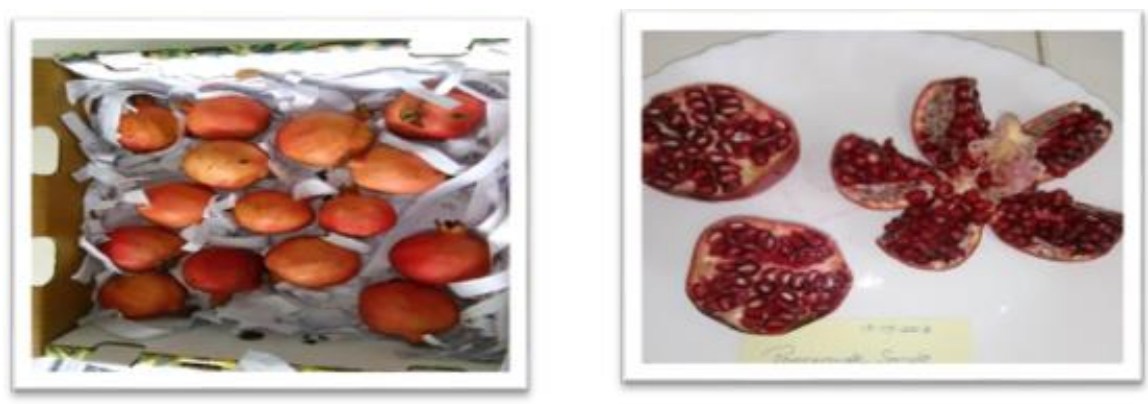

After 46 days

Plate1. Photos of Pomegranates inside cold room of Ecofrost.

Pomegranates are highly susceptible to weight loss due to high porosity of the fruit peel which permits free water vapor movement [2], and the susceptibility could depend on storage conditions and cultivar types. Temperature is a crucial variable, influencing the respiration rate of many fruits.

\section{CONCLUSION}

Weight loss was recorded inside cold room as $2.63 \%$ and $7.59 \%$ after 22 days and 30 days, respectively. Shelf life was recorded 6 days. Storage of pomegranate fruit cv. 'Bhagwa' inside cold room at temperature $7^{\circ} \mathrm{C}$ with $95 \%$ relative humidity along with $\mathrm{CFB}$ box with shredded paper maintain better performance.

\section{ACKNOWLEDGEMENT}

The authors are grateful to Directors of Ecofrost Technologies Pvt. Ltd., Survey no 134/1, 134/2, 130/3, Jeevan Nagar, Tathawade, Pune, Maharashtra- 411033 for providing facilities for conducting the research work.

\section{REFERENCES}

[1] Fawole, O.A. and Opara, U.L., Effects of storage temperature and duration on physiological responses of pomegranate fruit. Industrial Crops and Products. 47, Pp. 300-309 (2013).

[2] Elyatem, S.M. and Kader, A.A., Post-harvest physiology and storage behavior of pomegranate fruits. Sci. Hort., 24, Pp. 287-298 (1984).

Citation: Dr. Parag Babaji Jadhav et al., " Effect of Cold Storage on Weight Loss and Storage Life of Pomegranate Cv. "Bhagwa"," International Journal of Forestry and Horticulture (IJFH), vol. 5, no. 1, pp. 2830, 2019. Available: DOI: http://dx.doi.org/10.20431/2454-9487.0501005

Copyright: (C) 2019 Authors. This is an open-access article distributed under the terms of the Creative Commons Attribution License, which permits unrestricted use, distribution, and reproduction in any medium, provided the original author and source are credited. 